\title{
Study On the Biogas Yielding Potential of a Portable Bioreactor Using a Blend of Corn Cob and Rice Chaff Mixed With Goat and Dog Dungs
}

\author{
Okolie, N. $\mathrm{P}^{1}$; Onifade, A.K $\mathrm{K}^{2}$; Oladunmoye M. $\mathrm{K}^{2}$; Adegunloye, D. V ${ }^{2}$ \\ ${ }^{1}$ Department of Food technology, Yaba College of Technology, P.M.B. 2011, Yaba, Lagos, Nigeria. \\ ${ }^{2}$ Department of Microbiology, Federal University of Technology, Akure, , Nigeria.
}

\begin{abstract}
The study is to investigate the viability of corncob and rice chaff co-digested with goat and dog dungs in the production of biogas and the PCR detection of the methanogenic bacteria involved. The study was carried out at mesophillic condition between $\left(29.5-33^{\circ} \mathrm{C}\right)$ in a mini laboratory digester fabricated using guage 16 metal sheets with $80 \mathrm{~L}$ capacity for a 90 days retention time. Corn cob and rice chaff were shredded and mixed with water with ratio 4:1 and 3:1 (waste to water) respectively and mixed with goat and dog dungs with ratio 2:1 (waste to water) and digested anaerobically. The proximate analysis of all the substratesused were carried out and the result shows a $C: N$ (carbon, nitrogen ratio) that is appropriate for the biogas production. The result shows a yield of $15 \mathrm{~L}$ after 20days at temperature $31^{\circ} \mathrm{C}$ and $\mathrm{pH} 6.2$, there was a drop in the yield and then an increase from the 40th day of digestion. The cumulative production was $37 \mathrm{~L}$ at temperature $31^{\circ} \mathrm{C}$ and $p H$ 5.9. The bacteria isolated from the samples includes; E. coli, Proteusspp, Klebsiellapneumoniae,Serratia. spp, Flavimonas spp. The result revealed that this combination of substrates can yield significantly biogas.
\end{abstract}

Keywords: Viability, Corncob, rice chaff, dog dung, goat dung, co-digested, methanogenic, digester, anaerobically and substrates

\section{Introduction}

Biogas typically refers to a mixture of different gases produced by the breakdown of organic matter in the absence of oxygen. Biogas can be produced from raw materials such as agricultural waste, manure, municipal waste, plant material, sewage, green waste or food waste. Biogas is a renewable energy source and in many cases exerts a very small carbon footprint (Weilan, 2010).It is now widely accepted that it is caused by the rapidly increasing concentrations of greenhouse gas in the atmosphere, which is emitted mainly by the combustion of fossil fuels containing carbon like coal, oil, and natural gas. The rising greenhouse gas emissions, decreasing fossil fuel supplies and energy security have led to the introduction of renewable energy targets at national level (Smyth et al., 2011).

Biogas can be produced by anaerobic digestion with anaerobic organisms, which digest material inside a closed system, or fermentation of biodegradable materials. Biogas is primarily methane $\left(\mathrm{CH}_{4}\right)$ and carbon dioxide $\left(\mathrm{CO}_{2}\right)$ and may have small amounts of hydrogen sulfide, moisture and siloxanes. The gases methane, hydrogen, and carbon monoxide (CO) can be combusted or oxidized with oxygen. This energy release allows biogas to be used as a fuel; it can be used for any heating purpose, such as cooking. It can also be used in a gas engine to convert the energy in the gas into electricity and heat. Biogas can be compressed, the same way natural gas is compressed to $\mathrm{CNG}$, and used to power motor vehicles. In the UK, for example, biogas is estimated to have the potential to replace around $17 \%$ of vehicle fuel. It qualifies for renewable energy subsidies in some parts of the world. Biogas can be cleaned and upgraded to natural gas standards, when it becomes bio methane (Huertaset al., 2011).

\section{Materials And Methods}

The study was conducted using 80 liter metallic digester of height $60 \mathrm{~cm}$. The digester was designed and constructed with guage 16 metal sheets in a metal workshopin Lagos. Corn cob was procured from local roasted corn sellers in Lagos and the rice chaff was from a local rice milling industry in Ekiti State. The Corn cobs used for this study were milled using the dry attrition mill. This was to reduce their sizes and increase the surface area of the wastes for faster degradation. The rice chaff was boiled to reduce the lignin content which tends to prevent enzymatic breakdown of the chaff. The cobs and chaff were charged at the ratio of 4:1 (that is, water to wastes) and 3:1 for the chaffs, respectively. Goat dung was collected freshly (i.e. in the morning as first waste at dawn) from a local abattoir (Odoeran) inCele area of Lagos.The dog dung was collected at a veterinary outlet in Surulere Lagos. The goat and dog dungs was blended at ratio 2:1 and a slurry was formed which was mixed with the slurry from the feed stock. The slurries formed were closed air-tight and stirred intermittently and was then fed into the bioreactor. The moisture, crude protein, ash, fat, crude fiber and carbohydrate contents of the corncob, rice chaff, goat and dog dung were determined as described by AOAC (2005), The microbial 
load and types were determined following the method of Buchanan and Gibbons (1994). The digital pH meter (Model Eco testerpH2) was used to take the measurement of the $\mathrm{pH}$ in the bioreactor. The temperature of the bioreactor was measured by inserting the thermometer through the gas collection outlet at the top of the bioreactor and temperature was read off the thermometer. The quantity of gas produced was measured with a meter rule as follows: The total height of the bioreactor was measured and also the head space for the gas collection was also measured. Since there is a decomposition of the feedstock in the bioreactor during the fermentation, the air space increases and the increase in the airspace was measured and recorded as the equivalent volume occupied by the gas produced.

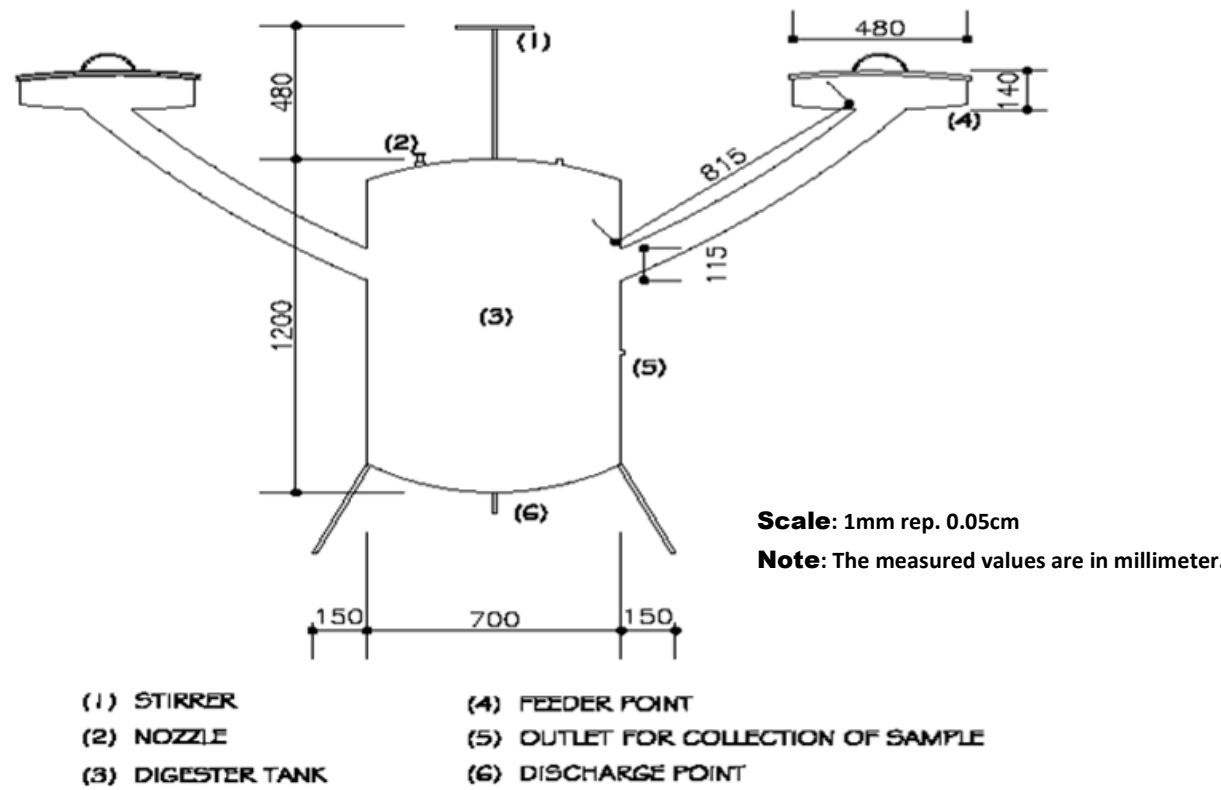

Figure 1: Diagram of the bioreactor

\section{Results And Discussion}

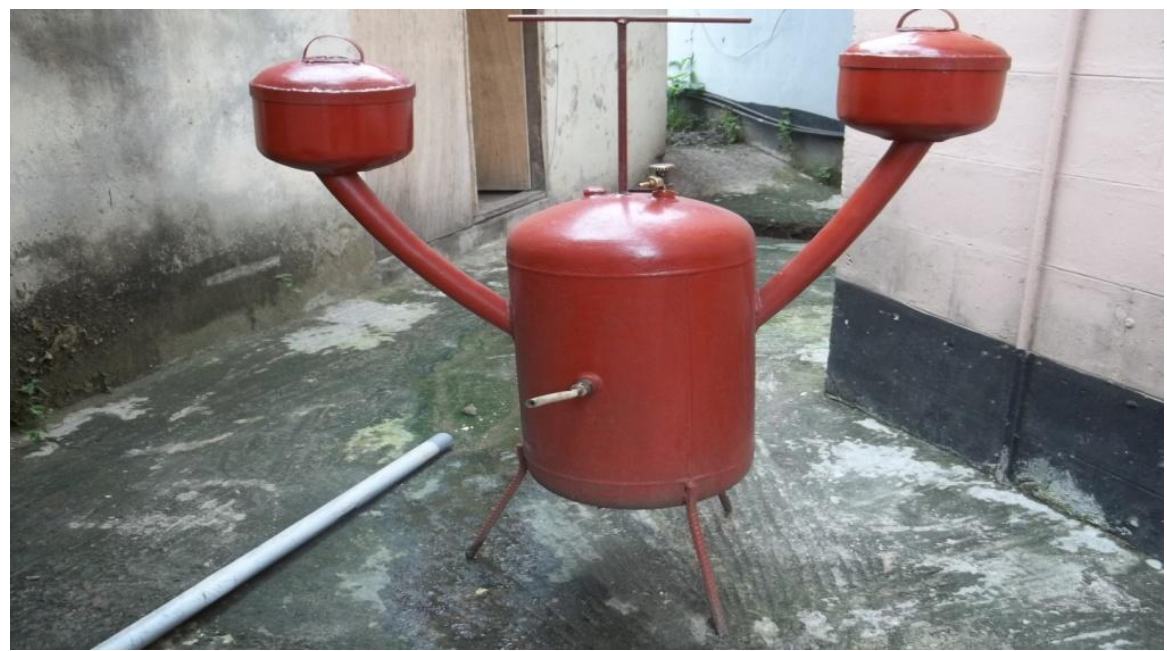

Plate 1: Showing photograph of constructed bioreactor

TABLE 1: Bacterial population

\begin{tabular}{lc}
\hline Sample & Total count cfu/g \\
\hline RICE & $3.8 \times 10^{4}$ \\
DOG dung & $35 \times 10^{7}$ \\
CORN Cob & $6.5 \times 10^{4}$ \\
GOAT dung & $68 \times 10^{7}$ \\
REACTOR & $76 \times 10^{8}$ \\
\hline
\end{tabular}

Dilution factor used $=10^{5} \quad$ Inoculum size $=50 \mu 1$ 
TABLE 2: Isolated organisms from the samples

\begin{tabular}{ll}
\hline SAMPLE & ORGANISMS \\
\hline RICE & Escherichia coli \\
DOG dung & Proteus sp, E. coli, Klebsiellapneumonia \\
CORN Cob & Escherichia coli, Klebsiellapneumonia \\
GOAT dung & Escherichia coli, K.pneumoniae, Serratiamarcescens \\
REACTOR & Escherichia Coli Flavimonasoryzihabitans \\
\hline
\end{tabular}

Table 3:Proximate composition (\%) of corncoband rice chaff (Substrate)

\begin{tabular}{lllllll}
\hline SAMPLE & MOISTURE & PROTEIN & ASH & CRUDE FIBRE & FAT & CARBOHYDRATE \\
\hline Corn cob & $11.28 \pm 0.45$ & $11.04 \pm 5.05$ & $3.61 \pm 0.60$ & $26.21 \pm 6.49$ & $3.19 \pm 3.15$ & $43.65 \pm 9.68$ \\
Rice chaff & $11.52 \pm 0.42$ & $11.26 \pm 5.04$ & $3.68 \pm 0.60$ & $26.75 \pm 6.55$ & $3.26 \pm 3.05$ & $44.55 \pm 9.67$ \\
\hline
\end{tabular}

Data were presented as mean \pm SE. Values with different alphabet letters along the same column (lower case) were significantly different $(\mathrm{P} \leq 0.05)$.

Table 4:Proximate composition (\%) of goatand dog (Substrate)

\begin{tabular}{lllllll}
\hline SAMPLE & MOISTURE & PROTEIN & ASH & CRUDE FIBRE & FAT & CARBOHYDRATE \\
\hline Goat dung & $83.9 \pm 0.99$ & $2.02 \pm 0.01$ & $0.38 \pm 0.08$ & $0.38 \pm 0.04$ & $6.67 \pm 0.07$ & $6.02 \pm 0.02$ \\
Dog dung & $62.46 \pm 1.85$ & $8.22 \pm 0.11$ & $1.01 \pm 0.02$ & $12.68 \pm 0.14$ & $0.34 \pm 0.03$ & $13.67 \pm 0.18$ \\
\hline
\end{tabular}

Data were presented as mean \pm SE. Values with different alphabet letters along the same column (lower case) were significantly different $(\mathrm{P} \leq 0.05)$.

TABLE 5: Biogas daily yield

\begin{tabular}{llll}
\hline Day & Temperature $\left({ }^{\mathbf{O}} \mathbf{C}\right)$ & $\mathbf{p H}$ & Yield (L) \\
\hline 1 & 30 & 6.9 & - \\
2 & 31 & 6.9 & - \\
4 & 29 & 6.8 & - \\
5 & 33 & 6.9 & - \\
10 & 30.5 & 6.7 & - \\
20 & 31 & 6.2 & 15 \\
21 & 29.5 & 5.9 & 15 \\
22 & 29.5 & 5.9 & 15 \\
25 & 35 & 5.8 & 18 \\
30 & 33 & 6.0 & 20 \\
31 & 33 & 6.0 & - \\
32 & 30 & 6.0 & - \\
33 & 36 & 6.0 & - \\
35 & 29.8 & 6.1 & - \\
40 & 32 & 6.2 & 30 \\
41 & 31 & 5.8 & 33 \\
42 & 30 & 6.1 & 30 \\
50 & 31 & 6.2 & 35 \\
51 & 28 & 6.1 & 35 \\
52 & 29.5 & 59 & 37 \\
55 & 30 & 6.0 & 37 \\
60 & 31 & 5.9 & \\
\hline
\end{tabular}

\section{Discussion}

The study was conducted using 80 litre metallic digester of height $60 \mathrm{~cm}$. The digesters was designed and constructed with gauge 16 metal sheets in the metal workshop of the Yaba College of Technology,Yaba,Lagos. This design was similar to that of Eze and Ojike (2012) with slight modification.The bioreactor is composed of a stirrer at the top to stir the slurry from time to time to aid even fermentation and to ensure proper yield of gas. This was recommended by Baker (2001). He stated that the digester content should be continuously or intermittently mixed to prevent separation; hence the need to inculcate a mixing device.Two arms are attached to the bioreactor, one on both sides with covers to fit.Theseservesas the feeding point where the feedstock and water were feedinto the bioreactor. It also has a gas outlet at the top where the gas yield would be collected.A burner was connected to this outlet to test the gas yield.Two outlets were also provided (one on the side and the other at the base) for collection of slurry sample and to empty the content of the bioreactor after use. A tripod stand was attached to the reactor to keep the base off the ground preventing damage to the bioreactor. All the components agree with the EPA (2010) description of the components of a typical domestic bioreactor system.

BIOREACTOR CAPACITY $=80$ Litre

BIOREACTOR HEIGHT $=60 \mathrm{~cm}$

FEED WEIGHT

CORN COB $=0.2 \mathrm{~kg}$ 


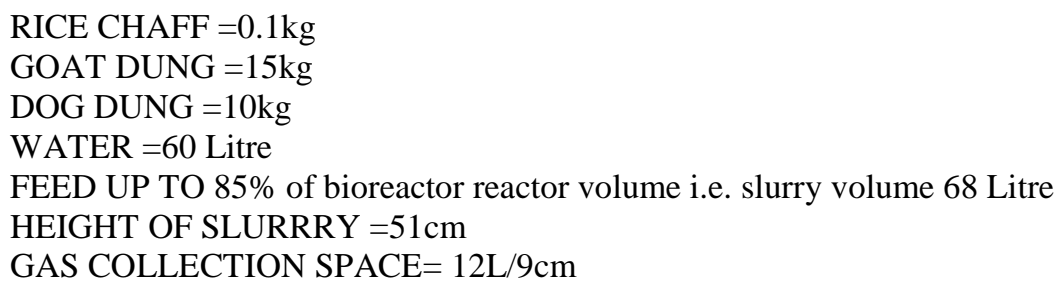

This gas tight bioreactor design is suitable for various types of anaerobic culture work and has been operated continuously for about 50 days without encountering a material failure. The completely closed system ensures that it is odor free and an outlet is created at the base of the reactor for easy discharges of effluent.

A study using this type of bioreactor design resulted in enhanced catabolism of organic acids and a $40 \%$ increase in the methane production (Smithet al., 1992).

The advantages of this design as observed over the operation periods includes the provision of proper sanitation by reducing the pathogenic content of substrate materials, hence its installation can dramatically improve the health of users. This is particularly the case where biogas plants are linked to public toilets and or where waste is no longer stored openly.Rapid public health improvements following biogas implement have been observed in rural China, with reduction in Stosomiasis and tapeworm of 90-99\% and 13\% respectively (Remaiset al., 2013).Solid retention time of 3 weeks at mesophilic condition are enough to kill pathogens leading to typhoid cholerawhile the benefits of this design includes low cost energy source, low cost fertilizer, reduced greenhouses emission,reduced nitrous oxide emission and less demand for alternative fuels.

This design is the batch flow digester design where the digester is loaded at once, maintained closed for a convenient period and the organic matter is fermented and then unloaded at a later time. It is quite a simple system.Biogas is collected in the upper chamber and the wastesin the lower chamber.

Land fill bioreactors are the most popular methods to produce biogas in the world due to the easiness of the operators and maintenance (Warithet al., 2005). Other anaerobic digester systems are expensive to construct and difficult to maintain compared to land fill bioreactors. The landfill bioreactors show long term biogas production due to the natural balance occurring in the reactor. In addition, there is no unfavorable odour released in this bioreactor due to proper covering of it.

The volume of gas generated during the digestion period is as shown in Table 5.There was no gas yield within the first 19days of digestion. This may be due to slow fermentation rate, similar to the study conducted by Eze and Ojike(2012) using maize wastefor biogas generation whereno gas yield was experienced within the first 9days of digestion; the gas only became flammable on the $10^{\text {th }}$ day. Vivekanandan and Kamaraj(2011) also carried out a study using cow dung as co-substrate with rice chaff at different substrate ratio and the first yield was noticed on the $3^{\text {rd }}$ day of digestion. The production day as recorded in this work may be due to slow rate of organic matter breakdown which may be as a result of the temperature and $\mathrm{pH}$ adjustment, however maintaining optimum temperature and $\mathrm{pH}$ makes the yield faster (Benson et al., 2007).The slow yield at the initial period may also be due to the time it takes for the microorganismsto acclimatize within the bioreactor. The gas becomes flammable on the 20th day with a yield of 15L. This is attributed to the better anaerobic environmental condition provided by the biogas with temperature and $\mathrm{pH}$ optimum for the activities of the microorganism in the digester. The yield could also be attributed to the high protein content in the feedstock which was degraded to cellulotic materials during fermentation to yield biogas by microorganism secreting some extra cellular enzymes (Oseni and Ekperigin, 2007). The volume of the yield remains the same from the $20^{\text {th }}$ day to the $22^{\text {nd }}$ and then increased to $18 \mathrm{~L}$ on the $25^{\text {th }}$ day. The increase is due to the catabolic and metabolic activities of the organism resulting in the breakdown of the organic matter in the digester to produce biogas.

The yield increased to $20 \mathrm{~L}$ on the $30^{\text {th }}$ day of the digestion and there was significant inactivity until the $40^{\text {th }}$ day when a yield of $30 \mathrm{~L}$ was observed. The same was observed for $31^{\text {st }}$ days in the work done by Vivekanandan and Kamaraj(2011) using rice chaff as a co-substrate with cow dung. They attributed the inactivity to the methanogens undergoing a metamorphic growth process which is in agreement with the findings of Dhaghat(2001) and Elijah et al. (2009). It is generally agreed that at the initial stages of the overall process of biogas production, acid forming bacteria produce volatile fatty acids (VFA) resulting in decline of $\mathrm{pH}$ and diminishing growth of methanogenic bacteria (Cuzinet al., 1992). The low $\mathrm{pH}$ value inactivated microorganismsresponsible for biogas production.

Ossai (2013)studied the comparative evaluation of qualitative and quantitative biogas production potential of oil palm frondsand co-digested with cow dung and reported a yield after 48hours of digestion although there was variation in the determined parameters. The palm fronds as single substrate was flammable in 2 days although gas production witnessed a slow progression at the start of the digestion between the $8^{\text {th }}$ and $11^{\text {th }}$ day after which an increased production was observed between the $12^{\text {th }}$ and the $18^{\text {th }}$ day of the 27 day digestion period. 
This report is similar to the yield observed in this work after the first 30days and then production of $30 \mathrm{~L}$ in the 40th day. In addition, the $\mathrm{pH}$ and temperature of the digester could contribute to the yield.It was observed that the temperature of the system was fluctuating between $29^{\circ} \mathrm{C}$ and $33^{\circ} \mathrm{C}$ and the $\mathrm{pH}$ was decreasing.Benson et al. (2007) reported that methane production increases with increase in temperature and most anaerobic temperature performed well at $\mathrm{pH}$ range of $6.8-7.2$.Therefore a fluctuation in this environmental condition also is responsible for the fluctuation in the yield. However, the temperature and $\mathrm{pH}$ of the digester was kept within the optimum level by proper monitoring throughout the digestion period.

This inactivity period was followed by a steady increase in yield from the $40^{\text {th }}$ day to the $60^{\text {th }}$ day with a cumulative yield of $37 \mathrm{~L}$. The high yield observed was due to the co-digestion of goat and dog dung with the feed stock (rice chaff and corncob),

Vivekanandan and Kamaraj (2011) used rice chaff and cow dung as co-substrate at two different ratios and the report showed that the digester case with the highest dung ratio produces the highest yield. Uzodinma and Ofoefile(2009) observed that the combination of dog and cow dung generated methane after 6days of digestion whereas dog dung alone generated methane after 20 days. They attributed this to the high ash and protein content of the dog dung, which is similar to high content recorded in this work (Table 4). This suggested why dog dung should not be used without blending with cow or goat dung as used in this work

Okoroigwe(2005) reported that the gas production rate obtained by blending cow dung with dog waste is an improvement over the sole digestion of dog wasteswith the blends producing higher biogas volume, and the cumulative yield of 37L over 60days in this work validated this. Vivekanandan and Kamaraj(2011) recorded no significant yield of gas when rice chaff alone was used as a feedstock for biogas production this was not the case in this work because the rice chaff used was pretreated by boiling which reduces the lignin content that was reported to be responsible for no yield experienced in the work of Vivekanadan and Kamaraj (2011).

Ossai(2013) attributed a low/decreased yield to decrease in $\mathrm{pH}$.The $\mathrm{pH}$ change was responsible for the high volatile solids, such as protein, lipids etc in the mixture which were converted more intensely into volatile fatty acid, and other acidic metabolites by the activities of aerobes and facultative aerobes which are subsequently metabolized by methanogenic bacteria to generate methane (Dennis and Burke, 2001;Iyagbaet al., 2009).

This follows the observation made earlier about the drop in the production of gas in this experiment. Low pH has been reported in previous studies by Chynoweth et al.(1993) andMohantyet al. (2004) to inhibit methanogenic bacteria that are responsible for biogas production.pH values less than 5 or greater than 8 has been reported in previous studies to rapidly inhibit methanogenesis (Garba and Sambo, 1992). In this study the $\mathrm{pH}$ range of 5.9 and 6.2 were observed and the highest yield was at $\mathrm{pH}$ 6.2.Ossai(2013) also reported that the yield from the blend of palm fond waste and cow dung generated a significantly higher quantity of flammable biogas of $170.4 \mathrm{~L}$ than that of the palm frond alone (98.5L) buttering further gas compared to using single feedstock or substrate. The improvement in cumulative gas production may be ascribed to synergy of the resulting mixture which favored gas production as well as optimizing the feed stock properties that apparently ensures adequate gas production like the volatile solids (which is the biodegradable portion of the waste) nutrient (crude fat and protein) and carbon nitrogen ration (C/N) (Agunwamba, 2001).

From Table 1 above, the corncob has a higher microbial load $6.5 \times 10^{4} \mathrm{cfu} / \mathrm{g}$ compared to ricechaff with $3.8 \times 10^{4} \mathrm{cfu} / \mathrm{g}$.Eze and Ojike (2012)who worked on the anaerobic production of biogas from maize waste, also recorded a higher concentration of microorganism in the corncob which makes itto bemore nutritious than the rice chaff as a feedstock in the bioreactor. The bioreactor has the highest concentration of microorganisms and this is due to the combination of the feedstock and the manure blended together in the bioreactor. Ezekoye (2013) worked on the characterization and storage of biogas production from the anaerobic digestion of cow dung, spent grain/cowdung and cassava peels/rice husk, recorded a higher microbial concentration in the blend of cassava peels/rice chaff and spentgrain/cow dung compared to using the cowdung alone.

The goat dung has a higher microbial load of $6.8 \times 10^{7} \mathrm{cfu} / \mathrm{g}$ compared to the dog dung which portrays the goat dung being more nutritious than the dogdung; however a blend of all the material that constituted the feedstock produces a higher concentration of microorganism than is obtained singly in each feedstock.

The bacteria isolated from the Rice chaff isE. coli, Proteus spp, Proteus spp is a genus of gram negative proteobacteria, Proteus bacilli are widely distributed in nature as saprophytes, being found in decomposing animal matter sewage and in human and animal feaces. They do not ferment lactose but have shown to be capable of lactose fermenters depending on the species in a triple sugar iron (TSI) test. It is oxidase negative but catalase and nitrate positive. Specific tests include: positive urease (which is the fundamental test to differentiate proteus from salmonella) (Matsuyama et al., 2000).

E. coli and Klebsiellapneumoniae were isolated from the dog dung, K.pneumoniae is a gram negative non motile, encapsulated lactose fermenting facultative anaerobic rod shaped bacterium, it occurs naturally in the soil and members of the Klebsiella genus typically express two types of antigens on their cell surface (Ryan and Ray, 2004). 
E. coli and K. pneumoniae were isolated from the Corncob, Serratia. Spp, Serratia is a genus of gram negative, facultative anaerobic rod shaped bacteria of the enterobacteriaceae family. E. coli and K. pneumoniae were isolated from the goat dung. Flavimonasspp and E. coli were isolated from the bioreactor. Flavimonasoryzihabitans, known previously as Pseudomonas oryzihabitans, and a member of the Centers for Disease Control group which is gram negative; that has rarely been implicated as human pathogens. It appears to be a soil and saprophytic organism that survives in moist environment and is indigenous to rice paddles (Kim et al.,2000).

The result for the microbial count obtained in this work is higher than that obtained by Ifeanyi and Ossai (2014).This is due to the combination of goat and dog dungs in this work as opposed to the cow dung used by Ifeanyi and Ossai. However, these values are lower compared to those obtained in this work as the higher blend ratios produces higher microbial concentration suggesting that using animal manure from different animals in combination increases the microbial concentration in a bioreactor. Goat dung has a higher microbial load compared to dog dung which portrays the goat dung as being more nutritious than the dog dung. However,ablend of all the material that constitutes the feedstock produces higher concentration of microorganism compared to the control which contains feedstock with no manure.

Table 3 shows the proximate composition of corn and rice chaff used in this experiment.The analysis shows varying difference in the composition of the two substrates. Rice chaff has a higher moisture content of $11.52 \%$ compared to $11.28 \%$ for Corncob this may be due to the fact that the corn cob used for this experiment was from a roasted corn which reduces the moisture content significantly [prior to sun drying] before it was further dried in the sun. Eze and Ojike(2012) recorded higher moisture content for corn cob which did nothave any negative effect on the yield of the biogas. However it must be ensured that the moisture content is not too high because the wetter the material used, the more volume and area it takes up relative to the levels of gas produced (Richard et al., 1994).

In addition, Cavalieri and Smith(1985) observed that the moisture content for Corncob can pose a challenge in the use for energy conversion and that cobs with moisture content between 10 and $30 \%$ is ideal for energy production which means the moisture content of the cob and chaff used in this experiment is ideal for energy production. The high protein and fat content of both Corn cob and Rice chaff used in thisstudymakes for high nutrient availability for the microorganism in the digester to use up making the degradation rate faster and enhancing the production of gas this was supported by the report of Ezekoye(2013) in the comparative study of biogas production using plantain / almond leaves and pig dung.He stated that the growth and catabolism of microbes needs various kinds of nutrient especially elements of carbon nitrogen and phosphorus, for high quality of methane.Carbon is required for building of the cell structure of the methanogenic bacteria.From the results presented in his work it was discovered that the value of protein / nitrogen, volatile solids, total solids and carbon in the samples decreased in percentage after digestion. Some of them were used up by the bacteria. Thissuggests that the high yield recorded in this work is enhanced by the combined nutrient content of the substrate mix. The ash and fibre content also reduced significantly after the digestion suggesting they are also used up during the digestion process by the microorganism. The same was observed for the pig dung used in the experiment by Ezekoye(2013) thereby suggesting that the protein content of the goat and dog dungs used in this experiment make for a high yield of biogas. This enhances the catabolism and the metabolism of the methane producing microbes (Methanogenes).Damisaet al. (2008) who compared the proximate composition of cellulose residues of corn straw and corncob as biomass materials observed a high crude protein content in corn cob compared to corn straw. The high protein content served as nitrogen source required for growth and efficient enzyme expression by the organism, the relatively high crude fibre in the corn cob and corn straw correlated with increase in xylose content (common sugar in hemicelluloses). Vaughan and Judd(2003), gave the variation of rice chaff proximate composition as protein $(20-40 \%)$, fat $(0-0.4 \%)$ crude fibre $(30-50 \%)$, ash $(15-20 \%)$ which falls in line with the result obtained in this study. The rice chaff contain high lignocelluloses material which could reduce the yield, therefore it was pretreated by boiling before use.

The carbohydrate content of both substrates shown in Table 3 is also high with Rice chaff having the highest $44.55 \%$ compared to $43.65 \%$ in corncob.Combination of the two substrates in co-digestion increases the carbohydrate content of the feedstock which amount to increased yield of biogas. High carbohydrate feedstock was recorded in the work of Eze and Ojike(2012) and this resultsinhigh yield of biogas. The energy content conversion of biomass such as Corncob used in this work is also connected to their carbohydrate content.Foley(1978) found that corn cob contains 32.3-45.6\% cellulose, 39.8\% hemicelluloses mostly composed of pentosan and $6.7-13.9 \%$ ligin. Cellulose is a polysaccharide of glucose units that serve as the main structural component of the cob's cell wall. Hemicelluloses are lesser complex polysaccharides that can more easily be broken down to simpler monosaccharaidessimple sugars. These materials are being broken down biologically to produce energy (gas).

The feed stock in this experiment is also co-digested with animal dungs (manure). Goat and Dog dung were used with the proximate composition as shown in Table 4. Okoroigwe (2005) and Maishanu and Maishanu 
(1998) generated biogas by combining Cow and Dog dung and reported a high yield due to the increased nutrient provided by the combined manure which makes for catabolism and metabolism of the methanogenic bacteria. The bacteria in the digester must have suitable food in order to grow and develop and this was supplied adequately by the goat and dog dung co-digested with the corncob and rice chaff.

The cumulative biogas yield of the palm fond was lower than the blend, palm frond contains high percentage of cellulose, hemi-cellulose pectin which are difficult to degrade and convert to biogas (Eze and Agbo, 2010).This is evident from the result obtained from the proximate analysis carried out on the wastes, the yield was enhanced by co-digestion of oil palm frond and Cow dung which re affirm previous findings that blending animal wastes and crop residues improves the blend digestibility and gas production arising from additional nutrients and gas improved carbon to nitrogen ration (Ezeet al., 2007;Iyagbaet al., 2009).

It was reported that animal manure alone actually provides a relatively small amount of biogas when compared to other feed stock, however combing animal waste with other feed stock as it is in this work would greatly increase biogas production With the right combination of animal waste and organic feed stock used in this experiment, the yield of biogas increases.

\section{Conclusion}

Different biomass materials have different biomass generation potential, this study investigated the biogas generation potential of corncob and rice chaff and co-digested with goat and dog dung in portable air tight bioreactor designed for anaerobic digestion of the substrate mix. The yield (biogas) produced shows that the feed stock used in the work has high biogas generating potential which shows that anaerobic digestion technique is aviableoption for generating energy at low cost while also combating environmental and health hazards that could result from indiscriminate disposal of the waste which serves as the material for the generation of utilizable energy. This low-cost bioreactor used in the experiment was found to be very reliable based on the reproducibility of the reactor conditions and minimal maintenance requirement. It offers a useful laboratory tool and represents a valuable contribution to the basic research in anaerobic digestion. Biogas technology offers a unique set of benefits. It can improve the health of users, is a sustainable source of energy, benefits the environment and provides a way to treat and reuse various wastes - human, animal, agricultural, industrial and municipal.

\section{References}

[1] Agunwamba, J. C. (2001). Waste: Engineering and Management Tools. Enugu, Nigeria. Immaculate Publications Ltd. p. 572.

[2] Baker, J. C. (2001). Methane Fuel Gas from Livestock Wastes - A Summary, North Carolina Sate University, Raleigh, NC, Last Electronic Revision: March 14, 2001

[3] Benson, C.H.; Barlaz, M.A.; Lane, D.T. and Rawe, J.M. (2007). Practice review of five bioreactor/recirculation landfills. Waste Management, 27(1):13-29.

[4] Cavalieri, A. J and Smith, O. S. (1985): Grain filling and field drying of a set of maize hybrids released from 1930 to 1982. Crop Sci., 25.856-860.

[5] Chynoweth, D. P., Turick, C. E.. Owens, J. M..Jerger, D. E..and Peck, M. W. (1993). Biochemical methane potential of biomass and waste feedstocks. Biomass and Bioenergy, 5:95-111.

[6] Cuzin, N, Farinet, J. L, Segretain, C. and Labat, M. (1992).Methanogenic fermentation of cassava peel using a pilot plug flow digester. Bioresource Technol. 41, 259-264

[7] Damisa, D., Amah, J.B and Umoh, V.J (2008).Effect of chemical pretreatment of some lignocellulosic wastes on the recovery of cellulose from AspergillusnigerAH3 mutant.African Journal of Bio-technology vol. 7(14), Pp. 2444 - 2450,18 July, 2008.

[8] Dennis, A. and Burke P. E. (2001). Dairy Waste Anaerobic Digestion Handbook = Options for Recovering Beneficial Products From Dairy Manure. Environmental Energy Company, 6007 Hill Street Olympia, WA 98516.www.makingenergy.com.

[9] Dhaghat, N. N (2001) Up flow anaerobic sludge blanket reactor. Rev. Indian. J. Environ. Health. 43, 1-82.

[10] Elijah, T. I., Ibifuro, A. M. and Yahaya, S. M. (2009) The study of cow dung as co-substrate with rice husk in biogas production. Scientific Res. \& Essay. 4 (9), 861-866.

[11] EPA, (2010): AgSTAR Handbook: A Manual for Developing Biogas Systems at Commercial Farms in the United States, available online at http://www.epa.gov/agstar/pdf/handbook/full pdf.pdf

[12] Eze, I. S., Anyanwu, C. N. Oparaku, O. U. and Okoye, C. O. B. (2007). Animal Manure: A Resource or a Waste? 37th Annual Conference of Nigerian Society of Chemical Engineers. http://www.nschef.org (accessed July, 2011)

[13] Eze, J. I and Ojike, .O. (2012). Anaerobic production of biogas from maize wastes. International Journal of Physical Sciences vol. 7 (6), pp. $982-987,2$ February, 2012.

[14] Eze, J. I, and Agbo, K. E (2010).Maximizing the potentials of biogas through upgrading.Am. J. Sci. Ind. Res., 1(3): 604-609.

[15] Ezekoye, V.A (2013). A comparative study of biogas production using plantain/almond leaves and pig dung and its application.International journal of physical sciences Vol. 8 (23), Pp. 1291 - 1297, 23 June, 2013.DOI: 10.5897/IJPs2013. 3909.

[16] Foley, K. (1978). Physical Properties, Chemical Properties and Uses of the Anderson's Corncob Products.The Andersons, Maumee, $\mathrm{OH}$.

[17] Garba, B. and Sambo, A.S. (1992).Effect of operating parameters on biogas production rates.Nigerian Journal of Renewable Energy, 3(1\&2): 36-44.

[18] Huertas, J.I., Giraldo, N. andIzquierdo (2011). "Removal of H2S and CO2 from Biogas by Amine Absorption", in Mass Transfer in Chemical Engineering (ed. J. Markos), ISBN 978-953-307-619-5, Intech, http://cdn.intechopen.com/pdfs-wm/22869.pdf

[19] Ifeanyi V.O,andOssai I. W. (2014). Analysis of Bio-gas Production from Cow Dung by Indigenous Microbial Consortia.British Biotechnology Journal. 2014 May; 4(5): 630-639.

[20] Iyagba, E.T., Mangibo, I.A., and Mohammed, Y.S (2009). The study of cow dung as a co-substrates with rice husk on biogas production. Scientific J. Research and essays. 4(9) : 861-866 
[21] Kim, Y. C., Jung, Y., Xuan, Z., Dong, H., Zhang, M. Q., and Wang, S. M (2000).Pan-genome isolation of low abundance transcripts using SAGE tag. Center for Functional Genomics ENH Research Institute, Northwestern University, 1001 University Place, Evanston, IL 60201 Tel: 224-364-7491; Fax: 224-364-5003; Email: swang1 @ northwestern.edu

[22] Liu, W.T., Marsh, T.L., Cheng, H., and Forney, L.J. (2011).Characterization of microbial diversity by determining terminal restriction fragment length polymorphisms of genes encoding RNA Appl. Environ.Microbiol.,63 (11) (1997), pp. 4516-4522

[23] Maishanu, S.M., Maishanu, H.M. (1998). "Influence of Inoculum Age on Biogas Generation from Cow Dung”.Nigerian Journal of Renewable Energy. 6(1 \& 2): $21-26$.

[24] Matsuyama, S., Llopis, J., Deveraux, Q. L., Tsien, R. Y. and Reed, J. C. (2000). Changes in intramitochondrial and cytosolic pH: Early events that modulate caspase activation during apoptosis. Nat. Cell Biol. 2: 318-325.

[25] Mohanty, R. K., Verma, H. N., and Brahmanand, P. S. (2004) Performance evaluation of rice-fish integration system in rainfed medium land ecosystem. Aquaculture 230: 125-135.

[26] Okoroigwe, E. C., (2005). Adaptation of plastic technology in the production of biogas digester.An M. Eng. Project Report.Department of Mechanical Engineering, University of Nigeria, Nsukkahttp://www.unn.edu.ng.

[27] Oseni, O. A., and Ekperigin, M. (2007). Studies on biochemical changes in maize wastes fermented with Aspergillusniger. Biokemistri, 19(2): 75-79.

[28] Ossai, O.S (2013). Comparative evaluation of qualitative and quantitative biogas production potential of oil palm fronds and codigestion with Cow dung.Journal of energy technologies and Policy ISSN 2224 - 3232 (paper) ISSN 2225 - 0573 (online) vol 3 , No. 4, 2013.

[29] Remais, J. V., Zeng, G., Li, G., Tian, L., and Engelgau, M. M. (2013).Convergence of non-communicable and infectious diseases in low- and middle-income countries.Int J Epidemiol 42:221-227.

[30] Richards, B.; Herndon, F. G.; Jewell, W. J.; Cummings, R. J.; and White, T. E. (1994)."In situ methane enrichment in methanogenic energy crop digesters". Biomass and Bioenergy 6 (4): 275-274. doi:10.1016/0961-9534(94)90067-1.

[31] Ryan, K. J, and Ray, C. G, (Eds): (2004). Sherris Medical Microbiology.4thedition.McGraw Hill; 556.566-569.

[32] Smith, W.H., Wilkie, A.C. and Smith, P.H. (1992).Methane from biomass and waste - a program review. TIDE (Teri Information Digest on Energy), 2(1):1-20 (1992). [PDF]

[33] Smyth, B. M., Symthm H. and Murphy, J.D. (2011). Determining the regional potential for a grass Biomethane industry. Applied Energy. 88:2037-2049.

[34] Uzodinma, E. O. and Ofoefule, A. U. (2009).Biogas production from blends of field grass (Panicum maximum) with some animal wastes.Int. J. Phys. Sci., 4: 091-095.

[35] Vaughan, J. G and Judd, P. A (2003).The Oxford book of health foods.Oxford Univ. Press. ISBN 0-19 - 85, 459 - 464

[36] Vivekanandan S. and Kamaraj G. (2011). The study of biogas production from rice chaff (karukka) as Co-substrate with cow dung.Indian journal of science and Technology, 4(6): (June 2011). ISSN: $0974-6846$.

[37] Warith, M., Li, X. and Jin, H. (2005). Bioreactor landfills: State-of-the-Art-Review. Envtl.J. for Engi.10(1): 1-14.

[38] Weiland, P., 2010. Biogas production: current state and perspectives. Applied Microbiology and Biotechnology, 85: 849-860 